\title{
Tulane
}

Tulane Economics Working Paper Series

\section{Re-designing Equalization Transfers: \\ An Application to South Africa's Provincial Equitable Share}

\author{
James Alm \\ Department of Economics \\ Tulane University \\ jalm@tulane.edu
}

\author{
Jorge Martinez-Vazquez \\ Andrew Young School of Policy Studies \\ Georgia State University \\ jorgemartinez@gsu.edu
}

Working Paper 1510

January 2015

\begin{abstract}
In this paper we examine the design of transfer systems, focusing on the Provincial Equitable Share (PES) in the Republic of South Africa. Provinces in South Africa have been assigned a wide range of responsibilities. Because provinces are almost completely reliant on transfers from the central government, the design of the PES is of critical importance, especially in its ability to achieve the goal of "equalization" across provinces. Our specific conclusion is that the PES largely fails in its efforts to equalize across provinces. Our more general conclusion that follows from this is that the PES attempts to achieve too many conflicting goals, and so it necessarily fails to achieve all goals equally or well, especially in its ability to equalize. We conclude with suggestions for ways to reform the PES to better achieve the goal of equalization, lesson that also apply to other countries.
\end{abstract}

Keywords: fiscal decentralization, equalization, fiscal capacity, expenditure norms JEL codes: H77, O12, P43 


\title{
Re-designing Equalization Transfers: An Application to South Africa's Provincial Equitable Share
}

\author{
James Alm \\ Tulane University, USA \\ Jorge Martinez-Vazquez * \\ Georgia State University, USA
}

\begin{abstract}
ABSTRAC T
In this paper we examine the design of transfer systems, focusing on the Provincial Equitable Share (PES) in the Republic of South Africa. Provinces in South Africa have been assigned a wide range of responsibilities. Because provinces are almost completely reliant on transfers from the central government, the design of the PES is of critical importance, especially in its ability to achieve the goal of "equalization" across provinces. Our specific conclusion is that the PES largely fails in its efforts to equalize across provinces. Our more general conclusion that follows from this is that the PES attempts to achieve too many conflicting goals, and so it necessarily fails to achieve all goals equally or well, especially in its ability to equalize. We conclude with suggestions for ways to reform the PES to better achieve the goal of equalization, lesson that also apply to other countries.
\end{abstract}

JEL Classifications: H77, O12, P43

Keywords: Fiscal Decentralization, Equalization, Fiscal Capacity, Expenditure Norms Corresponding Author's Email Address: jalm@tulane.edu

\section{INTRODUCTION}

The design of any system of transfers is a complex matter, and in practice very few countries are able to get it "right". The design must reflect often conflicting goals, such as promoting budget autonomy at the subnational level, providing adequate revenue to subnational governments, providing appropriate incentives (e.g., tax effort and revenue mobilization. expenditure efficiency, fiscal sustainability), enhancing equity and fairness, and achieving national objectives. At the same time it is imperative that the design be simple, transparent, and stable. Achieving all of these goals is a daunting task. The ability to achieve "fiscal equalization" is often of paramount importance. Fiscal 
equalization represents the transfer of resources across jurisdictions with the aim of equalizing the abilities of different governments to provide similar packages of public services with similar levels of taxation. It is largely intended to offset any imbalances, or differences, between governments that result from fiscal decentralization. Nearly all governments across the world have some form of equalization in their intergovernmental transfer systems. ${ }^{1}$

In this paper we examine the design of transfer systems, focusing on a single instrument in a single country: the Provincial Equitable Share (PES) in the Republic of South Africa, as administered by the Financial and Fiscal Commission. Provinces in South Africa have been assigned via the Constitution a wide range of responsibilities: providing basic services like education and health, administering social security grants, and delivering welfare programs. In their entirety, these provincial expenditure responsibilities account for nearly one-half of total government expenditures at all levels. However, provinces raise only about 1 percent of their own revenues. Instead of generating their own revenues, provinces are almost completely reliant on transfers from the central government, and the PES accounts for nearly all of these transfers. The design of the PES is therefore of critical importance to provincial governments and, more broadly, to the efficient and equitable delivery of a vast range of essential services in South Africa.

We examine the current practice of the PES, in order to evaluate its performance, especially its ability to equalize across provinces. Our specific conclusion is that the PES largely fails in its efforts to equalize across provinces. Our more general conclusion that follows from this is that the PES attempts to achieve too many conflicting goals, and so it necessarily fails to achieve all goals equally or well. Indeed, this conclusion reflects a broader lesson of policy design: it is impossible to achieve multiple goals with a single instrument. We conclude with suggestions for ways to reform the PES, and indeed the broader fiscal decentralization system, in order to better achieve the goal of equalization.

\section{SOME BASIC PRINCIPLES IN THE DESIGN OF INTERGOVERNMENTAL TRANSFERS}

There are several main elements in any decentralization strategy: assigning expenditure responsibilities to the different levels of government, assigning revenue responsibilities (including borrowing powers) to these governments, and designing transfer systems. Here we focus on some basic principles in transfer design. ${ }^{2}$

There are several main rationales for intergovernmental transfers. First, because the abilities of higher and lower levels of government to generate revenues often differ markedly, as do their expenditure responsibilities, transfers can improve the fiscal balance between these different levels of government (e.g., "vertical fiscal balance"). Second, the central government may place a higher priority on certain types of expenditures than do lower levels of government, so that transfers can encourage lower levels of government to expand their expenditures on these types of "merit goods". Third, transfers can provide an incentive for lower levels of government to expand public expenditures that have important spillover or externality effects on other jurisdictions. 
Finally, lower levels of government often differ significantly in their abilities to finance expenditures, with richer governments possessing greater resources to provide services than poorer governments. Transfers can help equalize these fiscal capacities between richer and poorer governments (e.g., "horizontal fiscal balance").

The types of intergovernmental transfers that emerge in theory from these different rationales are quite different. Transfers to deal with externalities should be open-ended, conditional, and matching transfers, with the matching rate reflective of the magnitude of the externality. Merit goods should be financed largely with closed-ended conditional transfers, whose amount is fixed and whose use is limited to the specific target. Transfers to address both vertical and horizontal fiscal balances should largely be unconditional and lump-sum transfers.

Even so, the actual design of any of these types of intergovernmental transfers requires many decisions to be made. Especially in the design of equalization transfers, there are many questions. How should expenditure needs be calculated? What categories of expenditures should be included in these calculations? Should capital expenditures be considered part of the calculations? How should fiscal capacities be calculated? Should actual or potential expenditures (or fiscal capacities) by used in the calculations? How should cost differences across governments be incorporated? Should equalization occur across expenditure needs, fiscal capacities, or both? How can these different measures be calculated in the absence of quality data on many of the relevant variables? How much equalization (of whatever type) should be achieved? From what source of central government revenue should equalization transfers be financed? Should these decisions made by use of some explicit and transparent formula or by some more ad hoc decision? Should these decisions be made by an independent grants commission or by a political body? These questions do not begin to exhaust the types of issues that must be confronted.

Different countries have answered these questions in many different ways. The next section discusses the specific choices that the Republic of South Africa has made in its Provincial Equitable Share.

\section{THE STRUCTURE OF THE PROVINCIAL EQUITABLE SHARE}

South Africa is country of 49 million people with great ethnic diversity. There are 11 official languages, and roughly 80 percent of the population is of black African ancestry, 9 percent is "white" (mainly of European descent), 9 percent is "coloured" (or mixed race), and 3 percent is "Asian" or "Indian". Its overall GDP places South Africa in the "middle-income" classification of the international organizations. Even so, in recent years nearly one-fourth of the working age population has been unemployed, and there is also substantial income inequality, with the income of the average white household nearly five times that of the average black household. There is also a large AIDSaffected segment of the population; the infection rate among adults is estimated at 20 percent, and over 30 percent of pregnant women were found in 2005 to be HIV-infected. Crime rates are also quite high. Since the end of apartheid in 1994, the dominant political party has been the African National Congress (ANC). 
There are nine different provinces, the largest of which are Gauteng (in which Johannesburg is located) and KwaZulu-Natal. These provincial governments have significant expenditure responsibilities, but little own-source revenues. Tables 1,2, and 3 , together with Figure 1, summarize the main features of provincial finances. Provinces are very heavily dependent on central government transfers for the vast bulk of their revenues. In this regard, the PES transfer plays a dominant role. In total, the distribution of the PES by province for 2008 is given in Table $4 .{ }^{3}$

The PES transfer is a formula driven grant program that distributes unconditional transfers to provinces. The formula is reviewed and updated annually with new data, with these updates phased in over a three-year period. The formula consists of six components that attempt to capture the relative demand for services between provinces and that take into account specific provincial circumstances. The components of the formula are neither indicative budgets nor guidelines as to how much should be spent on those functions in each province individually or by provinces collectively. Indeed, provincial executive councils have discretion regarding the determination of departmental allocations for each function, taking into account the priorities that underpin the division of revenue.

The distribution of the weights by component can vary from year to year, but the most recent (2013) distribution can be summarized as follows:

- An education share (51 per cent) based on the size of the school-age population (ages 5-17) and the number of learners (Grade R to 12) enrolled in public ordinary schools

- A health share (26 per cent) based on the proportion of the population with and without access to medical aid

- A basic share (14 per cent) derived from each province's share of the national population

- An institutional share (5 per cent) divided equally between the provinces

- A poverty share (3 per cent) reinforcing the redistributive bias of the formula

- An economic output share (1 per cent) based on GDP by region (GDPR) data. The weights assigned to the education (51 per cent) and health components ( 26 per cent) are derived from average provincial spending on education and health in total provincial spending for the past three years, excluding conditional grants. Consider each component in more detail. 
TABLE 1. ALLOCATION OF NATIONAL REVENUES TO SPHERES OF GOVERNMENT

\begin{tabular}{lcccccc}
\hline & \multicolumn{2}{c}{ 2005/06 } & \multicolumn{2}{c}{ 2006/07 } & \multicolumn{2}{c}{$2007 / 08$} \\
\hline Spheres of Government & $\begin{array}{c}\text { Revenue Allocation } \\
\text { (Mill. of Rands) }\end{array}$ & $\begin{array}{c}\text { Percentage } \\
\text { Share }\end{array}$ & $\begin{array}{c}\text { Revenue Allocation } \\
\text { (Mill. of Rands) }\end{array}$ & $\begin{array}{c}\text { Percentage } \\
\text { Share }\end{array}$ & $\begin{array}{c}\text { Revenue Allocation } \\
\text { (Mill. of Rands) }\end{array}$ & $\begin{array}{c}\text { Percentage } \\
\text { Share }\end{array}$ \\
\hline National & 194,723 & 53.24 & 212,629 & 50.87 & 246,937 & 50.47 \\
Provincial & 154,368 & 42.20 & 178,871 & 42.79 & 205,224 & 41.94 \\
Equitable Share & 135,292 & 36.99 & 150,753 & 36.07 & 172,862 & 35.33 \\
Conditional Grants & 19,076 & 5.22 & 28,118 & 6.73 & 32,362 & 6.61 \\
Local & 16,682 & 4.56 & 26,501 & 6.34 & 37,127 & 7.59 \\
Equitable Share & 9,643 & 2.64 & 18,058 & 4.32 & 20,676 & 4.23 \\
Conditional Grants & 7,038 & 1.92 & 8,443 & 2.02 & 16,451 & 3.36 \\
Total & 365,773 & 100.00 & 418,001 & 100.00 & 489,288 & 100.00 \\
\hline
\end{tabular}

Source: National Budget 2008 - Budget Review

TABLE 2. SOURCES OF PROVINCIAL REVENUES

\begin{tabular}{lcccccc}
\hline & \multicolumn{2}{c}{$2005 / 06$} & \multicolumn{2}{c}{$2006 / 07$} & & $2007 / 08$ \\
& $\begin{array}{c}\text { Amount } \\
\text { (Mill. of Rands) }\end{array}$ & $\begin{array}{c}\text { Percentage } \\
\text { Share }\end{array}$ & $\begin{array}{c}\text { Amount } \\
\text { (Mill. of Rands) }\end{array}$ & $\begin{array}{c}\text { Percentage } \\
\text { Share }\end{array}$ & $\begin{array}{c}\text { Amount } \\
\text { (Mill. of Rands) }\end{array}$ & $\begin{array}{c}\text { Percentage } \\
\text { Share }\end{array}$ \\
\hline Own Revenues & 7,379 & 4.58 & 7,954 & 4.94 & 7,673 & 4.76 \\
Transfers from National Government & 153,782 & 95.42 & 178,161 & 95.73 & 202,765 & 96.35 \\
Equitable Share & 135,292 & 83.95 & 150,753 & 81.00 & 171,271 & 81.39 \\
Conditional Grants & 18,490 & 11.47 & 27,408 & 14.73 & 31,494 & 14.97 \\
Total & 161,161 & 100.00 & 186,115 & 100.00 & 210,438 & 100.00 \\
\hline
\end{tabular}

Source: Intergovernmental Fiscal Review (IGFR) 2007 
TABLE 3. COMPOSITION OF OWN PROVINCIAL RECEIPTS
(PERCENT OF GDP)

\begin{tabular}{|c|c|c|c|c|c|c|}
\hline \multicolumn{7}{|l|}{ Percent of GDP at market prices } \\
\hline & $2002 / 03$ & $2003 / 04$ & $2004 / 05$ & $2005 / 06$ & $2006 / 07$ & $2007 / 08$ \\
\hline Total Provincial Own Receipts & 0.50 & 0.49 & 0.45 & 0.48 & 0.46 & 0.38 \\
\hline Tax receipts & 0.24 & 0.26 & 0.25 & 0.28 & 0.28 & 0.25 \\
\hline Of which:Casino taxes & 0.05 & 0.05 & 0.05 & 0.06 & 0.06 & 0.06 \\
\hline Horse racing taxes & 0.01 & 0.01 & 0.01 & 0.01 & 0.01 & 0.01 \\
\hline Motor vehicle licences & 0.18 & 0.20 & 0.19 & 0.21 & 0.21 & 0.18 \\
\hline Sale of goods and services other than capital assets & 0.10 & 0.10 & 0.09 & 0.09 & 0.08 & 0.08 \\
\hline Interest, dividends and rent on land & 0.13 & 0.08 & 0.06 & 0.06 & 0.06 & 0.04 \\
\hline Other receipts & 0.04 & 0.05 & 0.05 & 0.05 & 0.04 & 0.02 \\
\hline \multicolumn{7}{|l|}{ Percent of Total Own Receipts } \\
\hline $\begin{array}{l}\text { Total Provincial Own Receipts } \\
\text {. }\end{array}$ & 100 & 100 & 100 & 100 & 100 & 100 \\
\hline Tax receipts & 47.47 & 53.92 & 56.51 & 58.42 & 60.54 & 63.81 \\
\hline Of which:Casino taxes & 9.14 & 10.61 & 11.59 & 12.15 & 13.39 & 14.36 \\
\hline Horse racing taxes & 1.78 & 1.69 & 1.44 & 1.31 & 1.57 & 1.53 \\
\hline Motor vehicle licences & 36.29 & 41.38 & 43.20 & 44.72 & 45.33 & 47.44 \\
\hline Sale of goods and services other than capital assets & 19.80 & 20.17 & 20.67 & 18.32 & 18.01 & 19.95 \\
\hline Interest, dividends and rent on land & 25.39 & 15.77 & 12.52 & 13.45 & 12.23 & 10.75 \\
\hline Other receipts & 7.34 & 10.14 & 10.30 & 9.81 & 9.22 & 5.49 \\
\hline
\end{tabular}

Source: Intergovernmental Fiscal Review and Statistics South Africa

TABLE 4. DISTRIBUTION OF PROVINCIAL EQUITABLE SHARE BY PROVINCE, 2008 (PERCENT)

\begin{tabular}{|l|c|c|c|c|c|c|c|}
\hline & \multicolumn{9}{|c|}{ Component } \\
\hline Province & $\begin{array}{c}\text { Education } \\
\mathbf{( 5 1 \%} \\
\text { weight) }\end{array}$ & $\begin{array}{c}\text { Health } \\
\mathbf{( 2 6 \%} \\
\text { weight) }\end{array}$ & $\begin{array}{c}\text { Basic } \\
\text { Share } \\
\mathbf{( 1 4 \%} \\
\text { weight) }\end{array}$ & $\begin{array}{c}\text { Poverty } \\
\mathbf{( 3 \%} \\
\text { weight) }\end{array}$ & $\begin{array}{c}\text { Economic } \\
\text { Activity } \\
\mathbf{( 1 \%} \\
\text { weight) }\end{array}$ & $\begin{array}{c}\text { Institutional } \\
\mathbf{( 5 \%} \\
\text { weight) }\end{array}$ & $\begin{array}{c}\text { Weighted } \\
\text { Average } \\
(\mathbf{1 0 0 \%} \\
\text { total) }\end{array}$ \\
\hline Eastern Cape & 16.9 & 14.9 & 13.5 & 20.0 & 7.9 & 11.1 & 15.6 \\
\hline Free State & 5.7 & 6.2 & 5.7 & 6.9 & 5.5 & 11.1 & 6.1 \\
\hline Gauteng & 14.9 & 19.0 & 21.5 & 12.4 & 33.7 & 11.1 & 16.8 \\
\hline KwaZulu-Natal & 23.1 & 21.5 & 21.2 & 23.9 & 16.3 & 11.1 & 21.8 \\
\hline Limpopo & 14.1 & 12.0 & 10.8 & 16.0 & 6.7 & 11.1 & 13.0 \\
\hline Mpumalanga & 8.5 & 7.6 & 7.5 & 7.3 & 6.7 & 11.1 & 8.2 \\
\hline Northern Cape & 2.2 & 2.4 & 2.2 & 2.5 & 2.2 & 11.1 & 2.7 \\
\hline North West & 6.4 & 6.9 & 6.7 & 6.7 & 6.3 & 11.1 & 6.8 \\
\hline Western Cape & 8.1 & 9.6 & 10.9 & 4.2 & 14.7 & 11.1 & 9.0 \\
\hline Total & 100.0 & 100.0 & 100.0 & 100.0 & 100.0 & 100.0 & 100.0 \\
\hline
\end{tabular}

Source: Calculations by authors and Intergovernmental Fiscal Review and Statistics South Africa. 
FIGURE 1. COMPOSITION OF PROVINCIAL REVENUES, FY 2007/08

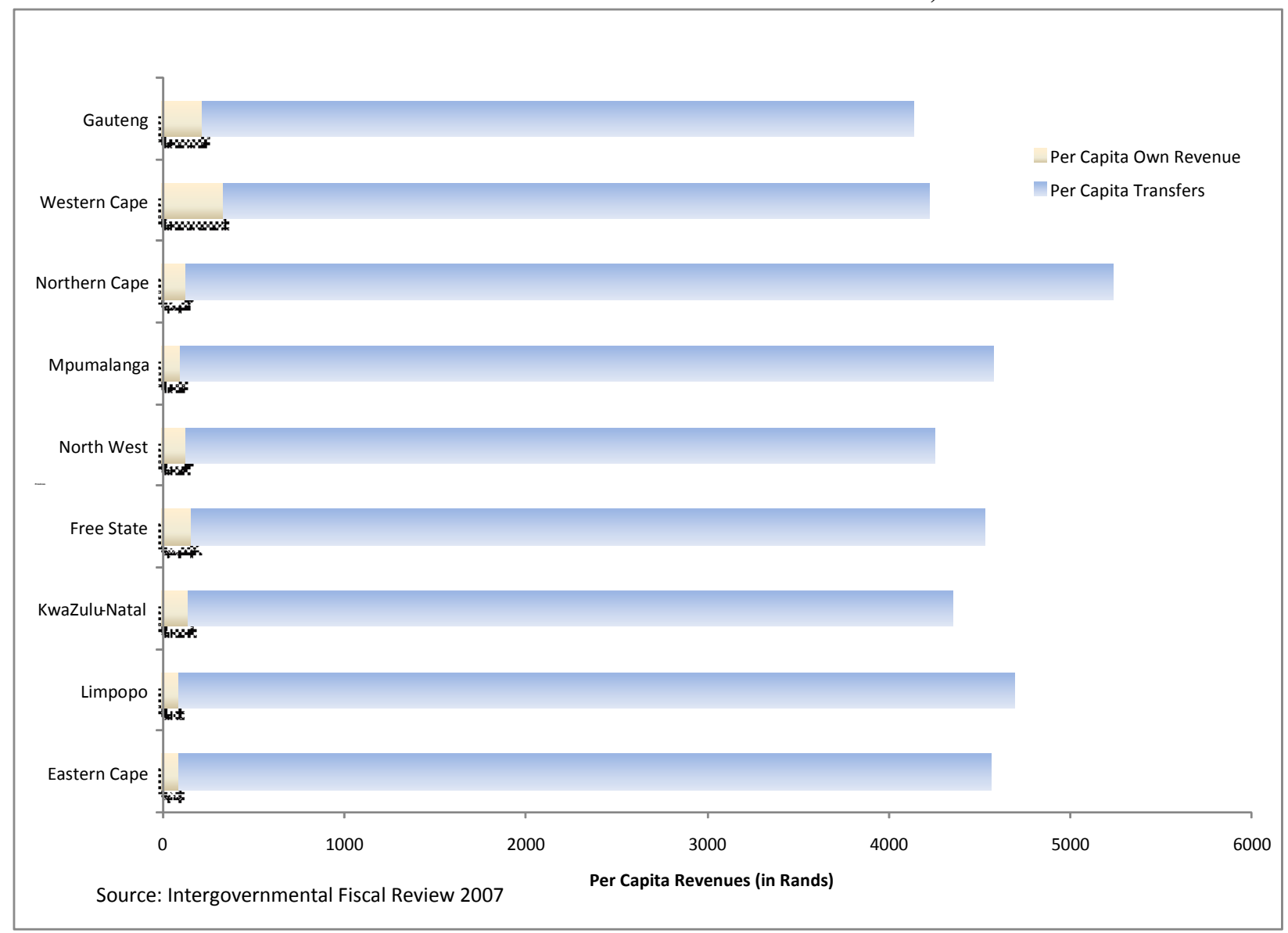


Education. The education component is intended to enable provinces to fund school education, which amounts to approximately 80 per cent of provincial education spending. The formula uses school-age population (5 to 17 years) based on Census 2001 and actual enrolment drawn from the 2007 Snap Survey to reflect relative demand for education, with each element assigned a weight of 50 per cent.

Health. The health component addresses the need for provinces to deliver health care. As all citizens are eligible for health services, the provincial shares of the total population form the basis for the health share. Within the health component, people without medical aid are assigned a weight four times those with medical aid, on the grounds that the former group is likely to use public health care more intensively.

Poverty. The poverty component introduces a redistributive element within the formula, and is assigned a weight of 3 per cent. The poor population comprises persons who fall in quintiles 1 and 2 based on the 2000 Income and Expenditure Survey. Each province's share is then expressed as the percentage of the "poor" population residing in that province.

Economic Activity. The economic activity component is a proxy for provincial tax capacity and is assigned a weight of 1 per cent.

Institutional. The institutional component recognizes that some costs associated with running a provincial government and providing services are not directly related to the size of a province's population. It is therefore distributed equally between provinces. This component constitutes 5 per cent of the total equitable share, of which each province receives 11.1 per cent.

Basic. The basic component is derived from the proportion of each province's share of the total population of the country and is assigned a weight of 14 per cent.

\section{EQUALIZATION UNDER THE PROVINCIAL EQUITABLE SHARE}

Given that a main goal of the PES is fiscal equalization, its ability to achieve this goal is of crucial importance. Unfortunately, the available evidence indicates quite clearly that the PES does not in fact achieve much equalization. This evidence comes from several sets of regressions. Table 5 presents various Ordinary Least Squares (OLS) regressions of the determinants of per capita PES transfers, non-PES transfers, and total transfers. Explanatory variables include variables meant to capture fiscal capacity (e.g., per capita GDP by region) and expenditures need (e.g., poverty ratio, percent urban population), plus provincial and regional dummy variables. Of some note, per capita regional GDP has an estimated coefficient that is always positive, so that higher income provinces tend to receive greater amounts of all transfers, not smaller amounts as required by equalization, although the coefficient is never significant. Similarly, the poverty ratio is never statistically significant. The percent urban has in some specifications a statistically significant coefficient; however, the sign of the coefficient is negative, so that more urban areas (or areas with greater expenditure needs) actually receive lower per capita transfers. Overall, the lack of equalization of any transfer is striking, but especially the lack of equalization from the PES.

Further, regression results for the determinants of provincial revenues (Table 6) demonstrate that higher income provinces tend to generate more revenues per capita, a 
counter-equalizing result. Similarly, regression results for the determinants of provincial expenditures (Table 6) find no statistical relationship between measures of expenditure needs and expenditures per capita, another counter-equalizing result.

This failure to achieve equalization arises from several related factors. One reason is that there is no sound methodology for quantifying expenditure needs. South Africa currently has explicit expenditure assignments, at least between the national sphere and the provinces. However, the current assignment of expenditure responsibilities has several important defects, all of which affect the perceived performance of the PES. Of most importance for the PES, there is currently no standard methodology or even widely accepted principle approved in any legislation for how to derive or estimate spending needs of provinces from the current assignment of expenditure responsibilities.

Without an approach to translate expenditure responsibilities into expenditure needs, the likelihood of frictions and misunderstandings between different spheres of government is likely to increase. Subnational governments may be unhappy because they feel that the current level of financing is not adequate for the responsibilities that have been assigned to them; the central authorities may argue that the current level of financing is more than adequate. The different rounds of discussions and position papers that may follow from either side on what to do about more financing via additional taxes, tax sharing, or other forms of transfers are likely to lead nowhere, as long as there is no transparency and no consensus on what are the expenditure needs of provincial governments.

In international practice, there are countries that, like South Africa, do not adopt an explicit methodology to arrive at the spending needs. ${ }^{4}$ However, there are many other countries that do adopt explicit methodologies, such as bottom-up costed standards of provision (e.g., Denmark, the Netherlands, and Japan), top-down financial per client norms(e.g., the United Kingdom, Ukraine, and some states in the U.S.), or historical costs (e.g., Russia and Spain). These different approaches are discussed in detail by Alm and Martinez-Vazquez (2002), who suggest two main lessons from international experience. First, countries without an explicit methodology to arrive at expenditure needs tend to function less smoothly unless their decentralization systems have been settled with trial and error over a long period spanning several decades. Second, there are better and worse methodologies for arriving at spending needs.

A second factor for the failure to equalize is that there is no significant consideration of fiscal capacity issues in the PES, where "fiscal capacity" is defined as the revenue that the provinces could raise given the taxes currently assigned to them, whether used or not used. Regardless of the appropriateness of the level of revenue autonomy and its use by the provincial governments, the issue of fiscal capacity is largely ignored in the formula of the PES. Per capita GDP by region receives a negligible weight of only 1 percent. Similarly, the poverty share has only a 3 percent weight, and poverty is only loosely connected to fiscal capacity anyway. Although there are some countries that disregard fiscal capacity issues in their transfer systems, many other decentralized systems in which provincial governments have their own revenue sources can and do equalize not only expenditure needs but also differences in fiscal capacity. As a result, these systems are able to equalize more successfully across subnational jurisdictions.

The question is whether South Africa should continue to ignore differences in fiscal capacity or whether a reformed PES system should incorporate them. The answer is 
likely to be complex and to depend on whether revenue autonomy will be increased and on how much any enhanced revenue autonomy will actually be used by the provinces. Because there are significant differences in the economic bases across provinces, more revenue autonomy will lead to greater horizontal disparities, and therefore will make it necessary to consider differences in fiscal capacity in the transfer system.

At any rate, possible changes in the formula of the PES transfer may consider the possibility of equalizing not only expenditure needs but also the differences between expenditure needs and fiscal capacity. Since their fiscal capacity will be counted for the transfers they get, whether the provinces use those sources or not, this could also be an incentive for them to start using the currently assigned sources and any other sources to be assigned in the future, especially if the simple conditional grant provides additional funds to those provinces that effectively have increased their fiscal effort. Of course, this would make the formula for the PES transfer much more redistributive.

In international experience there are countries that base their equalization systems on both differences in expenditure needs and difference in fiscal capacity (Australia, China, Germany, Japan, Latvia, Russia, Spain, and the United Kingdom); there are also countries that only take into account differences in expenditure needs (India and Italy); and there are countries that focus exclusively on the differences in fiscal capacity (Canada). The most common practice internationally is for equalization systems to capture disparities in both need and capacity.

A third factor is the seven different component weights in the PES formula. These weights may have had a historical basis, but they now look arbitrary. The current system of distributing the funds does not guarantee that the distribution of the funds reflects the government priorities concerning the different services being considered. There are other approaches that allow for these priorities to be reflected in the computation of expenditure needs, in large part by making the implicit weights endogenous and dynamic, as opposed to being arbitrarily fixed at some point in time. Indeed, given these weights, it should come as no surprise that the current formula is not very equalizing because it basically is population-based. 
TABLE 5. REGRESSION RESULTS FOR DETERMINANTS OF PER CAPITA INTERGOVERNMENTAL TRANSFERS ${ }^{a}$

\begin{tabular}{|c|c|c|c|c|c|c|c|c|c|}
\hline & \multicolumn{3}{|c|}{ PES } & \multicolumn{3}{|c|}{ Non-PES } & \multicolumn{3}{|c|}{ Total Transfers } \\
\hline $\begin{array}{l}\text { Independent } \\
\text { Variable }\end{array}$ & Equation1 & Equation2 & Equation3 & Equation1 & Equation2 & Equation3 & Equation1 & Equation2 & Equation3 \\
\hline Per Capita & 0.0179 & 0.0179 & 0.0179 & 0.0096 & 0.0096 & 0.0096 & 0.0275 & 0.0275 & 0.0275 \\
\hline GDPR & $(0.0178)$ & $(0.0178)$ & $(0.0178)$ & $(0.0101)$ & $(0.0101)$ & $(0.0101)$ & $(0.0198)$ & $(0.0181)$ & $(0.0188)$ \\
\hline Poverty & 0.0000 & 0.0132 & 0.0099 & 0.0000 & 0.0010 & 0.0016 & 0.0000 & 0.0142 & 0.0116 \\
\hline Ratio & $(0.0000)$ & $(0.0099)$ & $(0.0073)$ & $(0.0000)$ & $(0.0045)$ & $(0.0042)$ & $(0.0000)$ & $(0.0093)$ & $(0.0077)$ \\
\hline Percent Urban & $\begin{array}{c}0.0000 \\
(0.0000)\end{array}$ & & $\begin{array}{c}-0.0049 * * \\
(0.0020)\end{array}$ & $\begin{array}{c}0.0000 \\
(0.0000)\end{array}$ & & $\begin{array}{c}0.0009 \\
(0.0011)\end{array}$ & $\begin{array}{c}0.0000 \\
(0.0000)\end{array}$ & & $\begin{array}{l}-0.0040 * \\
(0.0021)\end{array}$ \\
\hline Year 2001 & $\begin{array}{c}-0.4567 * * * \\
(0.0536)\end{array}$ & $\begin{array}{c}-0.4567 * * * \\
(0.0527)\end{array}$ & $\begin{array}{c}-0.4567 * * * \\
(0.0520)\end{array}$ & $\begin{array}{c}0.4691 * * * \\
(0.0295)\end{array}$ & $\begin{array}{c}0.4691 * * * \\
(0.0306)\end{array}$ & $\begin{array}{c}0.4691 * * * \\
(0.0301)\end{array}$ & $\begin{array}{c}0.0124 \\
(0.0569)\end{array}$ & $\begin{array}{c}0.0124 \\
(0.0557)\end{array}$ & $\begin{array}{c}0.0124 \\
(0.0562)\end{array}$ \\
\hline Year 2002 & $\begin{array}{c}-0.5409 * * * \\
(0.0530)\end{array}$ & $\begin{array}{c}-0.5409 * * * \\
(0.0515)\end{array}$ & $\begin{array}{c}-0.5409 * * * \\
(0.0539)\end{array}$ & $\begin{array}{c}0.0054 \\
(0.0315)\end{array}$ & $\begin{array}{c}0.0054 \\
(0.0301)\end{array}$ & $\begin{array}{c}0.0054 \\
(0.0327)\end{array}$ & $\begin{array}{c}-0.5355 * * * \\
(0.0565)\end{array}$ & $\begin{array}{c}-0.5355^{* * * *} \\
(0.0570)\end{array}$ & $\begin{array}{c}-0.5355 * * * \\
(0.0585)\end{array}$ \\
\hline Year 2003 & $\begin{array}{c}-0.3901 * * * \\
(0.0540)\end{array}$ & $\begin{array}{c}-0.3901 * * * \\
(0.0549)\end{array}$ & $\begin{array}{c}-0.3901 * * * \\
(0.0531)\end{array}$ & $\begin{array}{c}0.0239 \\
(0.0308)\end{array}$ & $\begin{array}{c}0.0239 \\
(0.0339)\end{array}$ & $\begin{array}{c}0.0239 \\
(0.0328)\end{array}$ & $\begin{array}{c}-0.3662 * * * \\
(0.0559)\end{array}$ & $\begin{array}{c}-0.3662 * * * \\
(0.0562)\end{array}$ & $\begin{array}{c}-0.3662 * * * \\
(0.0570)\end{array}$ \\
\hline Year 2004 & $\begin{array}{c}-0.3003 * * * \\
(0.0573)\end{array}$ & $\begin{array}{c}-0.3003 * * * \\
(0.0579)\end{array}$ & $\begin{array}{c}-0.3003 * * * \\
(0.0571)\end{array}$ & $\begin{array}{c}0.0389 \\
(0.0322)\end{array}$ & $\begin{array}{c}0.0389 \\
(0.0326)\end{array}$ & $\begin{array}{c}0.0389 \\
(0.0301)\end{array}$ & $\begin{array}{c}-0.2613 * * * \\
(0.0615)\end{array}$ & $\begin{array}{c}-0.2613 * * * \\
(0.0595)\end{array}$ & $\begin{array}{c}-0.2613 * * * \\
(0.0608)\end{array}$ \\
\hline Year 2005 & $\begin{array}{c}-0.2378 * * * \\
(0.0632)\end{array}$ & $\begin{array}{c}-0.2378 * * * \\
(0.0647)\end{array}$ & $\begin{array}{c}-0.2378 * * * \\
(0.0631)\end{array}$ & $\begin{array}{l}0.0386 \\
(0.035)\end{array}$ & $\begin{array}{c}0.0386 \\
(0.0369)\end{array}$ & $\begin{array}{c}0.0386 \\
(0.0374)\end{array}$ & $\begin{array}{c}-0.1992 * * * \\
(0.0678)\end{array}$ & $\begin{array}{c}-0.1992 * * * \\
(0.0661)\end{array}$ & $\begin{array}{c}-0.1992 * * * \\
(0.0669)\end{array}$ \\
\hline Year 2006 & $\begin{array}{c}-0.2118 * * * \\
(0.0735)\end{array}$ & $\begin{array}{c}-0.2118 * * * \\
(0.0720)\end{array}$ & $\begin{array}{c}-0.2118 * * * \\
(0.0717)\end{array}$ & $\begin{array}{c}0.1267 * * * \\
(0.04138\end{array}$ & $\begin{array}{c}0.1267 * * * \\
(0.0423)\end{array}$ & $\begin{array}{c}0.1267 * * * \\
(0.0434)\end{array}$ & $\begin{array}{l}-0.0851 \\
(0.0755)\end{array}$ & $\begin{array}{l}-0.0851 \\
(0.0771)\end{array}$ & $\begin{array}{l}-0.0851 \\
(0.0765)\end{array}$ \\
\hline Year 2007 & $\begin{array}{l}-0.1405 \\
(0.0848)\end{array}$ & $\begin{array}{l}-0.1405 \\
(0.0831)\end{array}$ & $\begin{array}{l}-0.1405 \\
(0.0840)\end{array}$ & $\begin{array}{c}0.1342 * * * \\
(0.0483)\end{array}$ & $\begin{array}{c}0.1342 * * * \\
(0.0477)\end{array}$ & $\begin{array}{c}0.1342 * * * \\
(0.0474)\end{array}$ & $\begin{array}{l}-0.0063 \\
(0.0891)\end{array}$ & $\begin{array}{l}-0.0063 \\
(0.0875)\end{array}$ & $\begin{array}{l}-0.0063 \\
(0.0899)\end{array}$ \\
\hline Eastern Cape & & $\begin{array}{c}0.1394 \\
(0.1009)\end{array}$ & $\begin{array}{c}0.0120 \\
(0.0654)\end{array}$ & & $\begin{array}{l}-0.0006 \\
(0.0575)\end{array}$ & $\begin{array}{c}0.0225 \\
(0.0372)\end{array}$ & & $\begin{array}{c}0.1389 \\
(0.1065)\end{array}$ & $\begin{array}{c}0.0344 \\
(0.0690)\end{array}$ \\
\hline Free State & & $\begin{array}{l}-0.0672 \\
(0.0721)\end{array}$ & $\begin{array}{l}-0.0524 \\
(0.0766)\end{array}$ & & $\begin{array}{c}0.0039 \\
(0.0411)\end{array}$ & $\begin{array}{c}0.0012 \\
(0.0436)\end{array}$ & & $\begin{array}{l}-0.0633 \\
(0.0761)\end{array}$ & $\begin{array}{l}-0.0511 \\
(0.0809)\end{array}$ \\
\hline Gauteng & & $\begin{array}{c}-0.4335 * * \\
(0.1700)\end{array}$ & $\begin{array}{c}-0.3725^{* *} \\
(0.1564)\end{array}$ & & $\begin{array}{l}-0.0915 \\
(0.0968)\end{array}$ & $\begin{array}{l}-0.1026 \\
(0.0891)\end{array}$ & & $\begin{array}{c}-0.5251 * * * \\
(0.1794)\end{array}$ & $\begin{array}{r}-0.4751 * * * \\
(0.1651)\end{array}$ \\
\hline KwaZulu-Natal & & $\begin{array}{l}-0.0234 \\
(0.0915)\end{array}$ & $\begin{array}{c}-0.1315^{* *} \\
(0.0648)\end{array}$ & & $\begin{array}{l}-0.0650 \\
(0.0521)\end{array}$ & $\begin{array}{l}-0.0455 \\
(0.0369)\end{array}$ & & $\begin{array}{l}-0.0884 \\
(0.0966)\end{array}$ & $\begin{array}{c}-0.1770 * * \\
(0.0684)\end{array}$ \\
\hline Limpopo & & $\begin{array}{c}0.2302 * * \\
(0.0928)\end{array}$ & $\begin{array}{c}0.0000 \\
(0.0000)\end{array}$ & & $\begin{array}{l}-0.0416 \\
(0.0529)\end{array}$ & $\begin{array}{c}0.0000 \\
(0.0000)\end{array}$ & & $\begin{array}{l}0.1885^{*} \\
(0.0980)\end{array}$ & $\begin{array}{c}0.0000 \\
(0.0000)\end{array}$ \\
\hline Mpumalanga & & $\begin{array}{l}-0.0193 \\
(0.0900)\end{array}$ & $\begin{array}{c}-0.1771 * * * \\
(0.0633)\end{array}$ & & $\begin{array}{c}-0.1190 * * \\
(0.0513)\end{array}$ & $\begin{array}{c}-0.0904 * * \\
(0.0361)\end{array}$ & & $\begin{array}{l}-0.1382 \\
(0.0950)\end{array}$ & $\begin{array}{c}-0.2675 * * * \\
(0.0668)\end{array}$ \\
\hline North-West & & $\begin{array}{c}0.2442 * * \\
(0.0937)\end{array}$ & $\begin{array}{c}0.0721 \\
(0.0649)\end{array}$ & & $\begin{array}{l}-0.0687 \\
(0.0534)\end{array}$ & $\begin{array}{c}-0.0376 \\
(0.0370)\end{array}$ & & $\begin{array}{l}0.1755^{*} \\
(0.0990)\end{array}$ & $\begin{array}{c}0.0345 \\
(0.0685)\end{array}$ \\
\hline Western Cape & & $\begin{array}{c}0.0000 \\
(0.0000)\end{array}$ & $\begin{array}{c}0.0000 \\
(0.0000)\end{array}$ & & $\begin{array}{c}0.0000 \\
(0.0000)\end{array}$ & $\begin{array}{c}0.0000 \\
(0.0000)\end{array}$ & & $\begin{array}{c}0.0000 \\
(0.0000)\end{array}$ & $\begin{array}{c}0.0000 \\
(0.0000)\end{array}$ \\
\hline Constant & $\begin{array}{c}1.9249 * * * \\
(0.3720)\end{array}$ & $\begin{array}{l}1.3932 * \\
(0.7025)\end{array}$ & $\begin{array}{c}1.8775^{* * * *} \\
(0.6058)\end{array}$ & $\begin{array}{c}0.0361 \\
(0.2120)\end{array}$ & $\begin{array}{c}0.0378 \\
(0.4002)\end{array}$ & $\begin{array}{l}-0.0498 \\
(0.3451)\end{array}$ & $\begin{array}{c}1.9610 * * * \\
(0.3928)\end{array}$ & $\begin{array}{l}1.4310^{*} \\
(0.7416)\end{array}$ & $\begin{array}{c}1.8277 * * * * \\
(0.6395)\end{array}$ \\
\hline $\begin{array}{l}\text { Observations } \\
\text { R-squared }\end{array}$ & $\begin{array}{c}72 \\
0.76\end{array}$ & $\begin{array}{c}72 \\
0.87\end{array}$ & $\begin{array}{c}72 \\
0.87\end{array}$ & $\begin{array}{c}72 \\
0.87\end{array}$ & $\begin{array}{c}72 \\
0.89\end{array}$ & $\begin{array}{c}72 \\
0.89\end{array}$ & $\begin{array}{c}72 \\
0.79\end{array}$ & $\begin{array}{c}72 \\
0.85\end{array}$ & $\begin{array}{c}72 \\
0.85\end{array}$ \\
\hline
\end{tabular}

${ }^{a}$ The dependent variable and Per Capita GDPR are in constant 2000 prices. Per capita GDPR is in thousands of Rands. The base year is 2000 , and the base province is Northern Cape. Standard errors are in parentheses. * significant at $10 \%$; ** significant at 5\%; *** significant at $1 \%$. Source: Calculations by authors. 
TABLE 6. REGRESSION RESULTS FOR DETERMINANTS OF PER CAPITA PROVINCIAL TOTAL REVENUES AND TOTAL EXPENDITURES ${ }^{a}$

\begin{tabular}{|c|c|c|c|c|}
\hline & \multicolumn{2}{|c|}{ Total Revenues } & \multicolumn{2}{|c|}{ Total Expenditures } \\
\hline Independent Variables & Equation1 & Equation2 & Equation1 & Equation2 \\
\hline Per Capita GDPR & $\begin{array}{l}0.0314 * \\
(0.0186)\end{array}$ & $\begin{array}{l}0.0314 * \\
(0.0186)\end{array}$ & $\begin{array}{c}0.0164 \\
(0.0159)\end{array}$ & $\begin{array}{c}0.0164 \\
(0.0159)\end{array}$ \\
\hline Poverty Ratio & & $\begin{array}{c}0.0108 \\
(0.0082)\end{array}$ & & $\begin{array}{l}-0.0001 \\
(0.0069)\end{array}$ \\
\hline Percent Urban & $\begin{array}{c}0.0019 \\
(0.0012)\end{array}$ & $\begin{array}{c}0.0015 \\
(0.0012)\end{array}$ & $\begin{array}{l}-0.0010 \\
(0.0012)\end{array}$ & $\begin{array}{l}-0.0010 \\
(0.0012)\end{array}$ \\
\hline Year 2001 & $\begin{array}{c}0.0114 \\
(0.0561)\end{array}$ & $\begin{array}{c}0.0114 \\
(0.0561)\end{array}$ & $\begin{array}{l}-0.0105 \\
(0.0476)\end{array}$ & $\begin{array}{l}-0.0105 \\
(0.0476)\end{array}$ \\
\hline Year 2002 & $\begin{array}{c}-0.5336 * * * \\
(0.0559)\end{array}$ & $\begin{array}{c}-0.5336 * * * \\
(0.0559)\end{array}$ & $\begin{array}{c}-0.4529 * * * \\
(0.0476)\end{array}$ & $\begin{array}{c}-0.4529 * * * \\
(0.0476)\end{array}$ \\
\hline Year 2003 & $\begin{array}{c}-0.3658 * * * \\
(0.0566)\end{array}$ & $\begin{array}{c}-0.3658 * * * \\
(0.0566)\end{array}$ & $\begin{array}{c}-0.3257 * * * \\
(0.0482)\end{array}$ & $\begin{array}{c}-0.3257 * * * \\
(0.0482)\end{array}$ \\
\hline Year 2004 & $\begin{array}{c}-0.2664 * * * \\
(0.0598)\end{array}$ & $\begin{array}{c}-0.2664 * * * \\
(0.0598)\end{array}$ & $\begin{array}{c}-0.3064 * * * \\
(0.0509)\end{array}$ & $\begin{array}{c}-0.3064 * * * \\
(0.0509)\end{array}$ \\
\hline Year 2005 & $\begin{array}{c}-0.1980 * * * \\
(0.0661)\end{array}$ & $\begin{array}{c}-0.1980 * * * \\
(0.0661)\end{array}$ & $\begin{array}{c}-0.2025 * * * \\
(0.0561)\end{array}$ & $\begin{array}{c}-0.2025 * * * \\
(0.0561)\end{array}$ \\
\hline Year 2006 & $\begin{array}{l}-0.0892 \\
(0.0757)\end{array}$ & $\begin{array}{l}-0.0892 \\
(0.0757)\end{array}$ & $\begin{array}{c}-0.1618 * * \\
(0.0640)\end{array}$ & $\begin{array}{c}-0.1618 * * \\
(0.0640)\end{array}$ \\
\hline Year 2007 & $\begin{array}{l}-0.0287 \\
(0.0886)\end{array}$ & $\begin{array}{l}-0.0287 \\
(0.0886)\end{array}$ & $\begin{array}{l}-0.1418^{*} \\
(0.0747)\end{array}$ & $\begin{array}{l}-0.1418^{*} \\
(0.0747)\end{array}$ \\
\hline Easter Cape & & $\begin{array}{l}0.2025^{*} \\
(0.1054)\end{array}$ & & $\begin{array}{c}0.3168 * * * \\
(0.1157)\end{array}$ \\
\hline Free State & & $\begin{array}{l}-0.0293 \\
(0.0753)\end{array}$ & & $\begin{array}{c}0.0831 \\
(0.0716)\end{array}$ \\
\hline Gauteng & & $\begin{array}{c}-0.6061 * * * \\
(0.1775)\end{array}$ & & $\begin{array}{c}0.0956 \\
(0.6023)\end{array}$ \\
\hline KwaZulu-Natal & & $\begin{array}{l}-0.0682 \\
(0.0956)\end{array}$ & & $\begin{array}{c}0.1837 \\
(0.1576)\end{array}$ \\
\hline Limpopo & & $\begin{array}{c}0.2432 * * \\
(0.0969)\end{array}$ & & $\begin{array}{c}0.3066 * * * \\
(0.1109)\end{array}$ \\
\hline Mpumalanga & & $\begin{array}{l}-0.1693 * \\
(0.0940)\end{array}$ & & $\begin{array}{l}-0.1486 \\
(0.0946)\end{array}$ \\
\hline North-West & & $\begin{array}{l}0.1708^{*} \\
(0.0979)\end{array}$ & & $\begin{array}{c}0.0570 \\
(0.0903)\end{array}$ \\
\hline Western Cape & & $\begin{array}{c}0.0000 \\
(0.0000)\end{array}$ & & \\
\hline Constant & $\begin{array}{c}1.9820 * * * \\
(0.3886)\end{array}$ & $\begin{array}{l}1.5812 * * \\
(0.7338)\end{array}$ & $\begin{array}{c}1.8249 * * * \\
(0.3292)\end{array}$ & $\begin{array}{c}1.7280 * * * \\
(0.6209)\end{array}$ \\
\hline Observations & 72 & 72 & 72 & 72 \\
\hline R-squared & 0.79 & 0.85 & 0.75 & 0.83 \\
\hline
\end{tabular}

Source: Calculations by authors. 


\section{CONCLUSIONS: REFORMING THE PROVINCIAL EQUITABLE SHARE}

Our main specific conclusion is that the PES largely fails in its efforts to equalize across provinces. Given this failure to achieve any significant degree of equalization, it is worthwhile to consider possible reforms of the transfer to better achieve this goal. In this final section we first examine changes in specific features of the PES that address some of the problems that have been identified earlier. We then consider some more general implications of our analysis for the South System of fiscal decentralization.

The broad thrust of any PES reforms is to retain most of its current structure, but also to bring the PES closer to a conventional equalization grant. The basic principle that underlies any reforms is a simple one: reform of the PES equalization grant formula should reflect both expenditure needs and fiscal capacities.

How might such reforms work?

The basic structure of any equalization transfer system is typically based on a formula of the following type:

$$
D_{i}=E N_{i}-F C_{i}
$$

where $D_{i}$ corresponds to the fiscal disparity of subnational government $i, E N_{i}$ is the expenditure needs of government $i$, and $F C_{i}$ is its fiscal capacity. Whenever the fiscal disparity is positive, the expenditure needs exceed the fiscal capacity of the subnational government, and a transfer is necessary in order to improve its fiscal situation. In contrast, if $D_{i}$ is negative, then the subnational government has more resources than it needs (according to the established standards), and no transfer is justified. Then, representing the available equalization transfer fund as $X$ and the population of subnational government $i$ as $H_{i}$, the computation of the equalization transfer $T_{i}$ for subnational government $i$ can be calculated as:

$$
T_{i}=\frac{D_{i}^{*}}{\sum D_{i}^{*}} \cdot H_{i} \cdot X,
$$

where $D_{i}{ }^{*}$ corresponds exclusively to per capita fiscal disparities with a positive sign. ${ }^{5}$ Thus, the computation of the equalization transfers incorporates only those subnational governments where per capita expenditure needs are higher than per capita fiscal capacity. ${ }^{6}$

Of course, the difficult issues relate to measuring expenditure needs and fiscal capacity. Regarding expenditure needs, there are several acceptable approaches for quantifying the expenditure needs, including: equal per capita amounts; the use of historical values and lagged expenditures (which relies on historical expenditure patterns to estimate the expenditure needs of local governments); "per-client financial expenditure standards or norms" (sometimes called "top-down norms"); and a more bottom-up "costed norms" approach that calculates the resources needed by a provincial government in providing basic levels for each category of service (or the "cost"), given nationally mandated standards (or the "norms") for each service. ${ }^{7}$ The most sophisticated and data intensive approach is a "representative expenditure system" approach, often used in countries like the United States and Canada. 
International practice suggests that perhaps the most expedient approach would be to use for each major expenditure responsibility a methodology for the computation of needs based on a top-down per-client financial expenditure norms approach, adjusted for different costs of provision across the provinces. These norms can be discussed in conjunction with the sector departments and the provincial governments, but ultimately will need to settled and determined by the national budget authorities at budget time.

The calculation of expenditure needs using the per-client financial expenditure norms methodology requires several steps:

- The categorization of the main expenditure groups according to the assignment of expenditure responsibilities in the law.

- The identification of the number of clients for the relevant categories of expenditures (e.g., the number of school-age children in the province in the case of basic education, or the weighted population with higher weights for population under 12 , over 65 , and females of child-bearing age for the case of health)

- The determination of overall budget envelopes that can be spent in each major expenditure group.

The national per-client financial norm is then established by dividing the budget envelope by the number of clients. The expenditure norm so calculated is common to all jurisdictions, which in the absence of other variations in cost provision may be interpreted as the per-client expenditure need of the specific service funded by the program. To arrive at the expenditure needs of each province for the year, one simply multiplies the common expenditure norm by the number of clients in each province and then adds those amounts across all expenditure categories. The national expenditure norm in each category can also be adjusted for differences in the cost of delivery arising from different prices, different geographical conditions and access, and so on.

There are advantages and disadvantages of the various approaches, including the per-client financial expenditure norms approach adjusted for different costs. With this approach there is no need to determine a priori physical standard of provision (e.g., teacher/student ratio in primary education). This allows by-passing the difficulties of agreeing on the nature of the physical standards and on the necessary methodology and difficulties of costing them. However, one may feel uncomfortable with setting a financial standard that does not give much concrete intuition into what it is that a government is buying (although it does give information on what is affordable). The perclient financial expenditures norms approach is be transparent because one needs to explicitly state what funds are available and how each service needs to compete for the available funds; it also offers guarantees that the budget will remain balanced. ${ }^{8}$

Regarding fiscal capacity, the introduction of fiscal capacity measures in the PES formula would enhance its power to equalize across provinces. Just as with the estimation of expenditure needs, there are various approaches to estimation fiscal capacity, such as the use of lagged own revenues, the identification of basic proxies for the ability to tax (e.g., per capita income), and the use of a "representative tax system", which measures the amount of revenue that would be obtained by a locality if an average level of fiscal effort is exerted. ${ }^{9}$

The simplest approach is to use some measure of lagged revenues as a measure of fiscal capacity. This approach assumes that own revenues during a relevant period are 
representative of the fiscal capacity of the local government. There are at least two reasons why this assumption may not be appropriate. There may well be factors that create a gap between the amount of taxes actually collected and the fiscal capacity of a local government (e.g., different definitions of taxable income by which two local governments may not collect the same level of taxes even though they have the same fiscal capacity). Also, the use of current revenues may provide perverse incentives to government authorities. If local authorities "learn" that less own revenues in the present might be totally or at least partially counterbalanced in the future with greater transfers, then they could be tempted to reduce their fiscal effort.

Appendices A and B give examples of different methods to calculate expenditure needs and fiscal capacity in South Africa. These methods require substantial amounts of information, they are straightforward to introduce (at least, given these data), and they would improve the ability of the PES to equalize across provincial governments, as demonstrated by the resulting estimates. ${ }^{10}$

There is also a more general conclusion that follows from our analysis: the PES attempts to achieve too many objectives, and does not achieve any one clearly or well. The most basic principle of policy design is to use one separate instrument for each different objective. The PES formula violates this principle. A common problem in many countries with the design of transfers like equalization grants is that they get overloaded with so many policy objectives that at the end it is not at all clear what is pursued or achieved with the transfer system. This is certainly the case with the PES.

For example, what is the primary goal of the PES? Is it to equalize, distribute, or redistribute public funds to the provinces? Is it instead a general funding mechanism to enable the provinces to deliver constitutionally mandated services? Is it other things? Also, in clarifying the main objective of the PES, there is another important policy aspect that must be clarified: whose priorities should be pursued in the application of PES funds? Is it central government objectives that should be pursued, or should provinces be able to fix their own priorities in the application of PES funds?

Answers to these questions will dictate changes in the PES. To illustrate, suppose that the PES is defined mainly as a constitutional entitlement on central government revenues for each sphere of government. In this view the PES formula should be concerned with how the shares can be allocated equitably. However, an equitable distribution formula is not necessarily equivalent to an equalization formula in the traditional sense of addressing fiscal gaps or horizontal disparities between subnational government units. The notion of equity may require the distribution of funds for reasons other than achieving greater equality, such as providing more funds to those regional governments that are more entitled for some reason (e.g., the presence of natural resources in their territories). Also, the current "economic activity" component of the formula is nothing more than some form of revenue sharing on a derivation basis. Revenue sharing is a transfer used in many countries as a solution to closing vertical imbalances (since central governments collect much more than the expenditure responsibilities demand), and it may also be a way to let richer subnational governments get their share in the wealth/revenues collected in their territories. As such, South Africa can also make use of revenue sharing, but this "economic activity" component does not really belong in a traditional equalization transfer. Indeed, in most countries revenue sharing is arranged separately from other transfers, including equalization transfers. 
It is crucial that all of these issues be addressed in any reforms of the PES. Overall, we believe that these reforms, either singly or jointly, would improve the performance of the PES. Indeed, it may even be desirable to take a broader reform perspective, which reforms all of the major pillars of the South Africa fiscal decentralization system. This latter approach starts with the realization that fixing the PES requires fixing other aspects of the current fiscal decentralization system; that is, the reform of the PES would require such steps as getting clearer expenditure assignments by explicitly addressing the issue of voluntary (or "own") versus mandatory (or "delegated") responsibilities of provincial and other subnational governments, providing all subnational governments with more revenue autonomy, and encouraging all subnational governments to use more fully their tax autonomy. We believe that pursuing such broader reforms would also likely improve the performance of both the PES and the entire South African decentralization system. However, such a broader reform agenda is clearly more difficult to achieve.

In summary, there are several clear options to reform the current architecture and performance of the PES. All of them will require making the goals of government much more explicit than they are currently, and all of them may also contribute to the broader reform of South Africa's fiscal decentralization system.

\section{APPENDIX A. COMPUTING FINANCIAL EXPENDITURE NORMS}

\section{Method: "Financial Expenditure Norms"}

Step 1: Determine the aggregate level of provincial expenditures per function $j\left(S E N_{j}\right)$, the disaggregated provincial expenditures per function $j$ and per province $i\left(S E N_{j i}\right)$, and the number of potential users of each function $j$ at the national level $\left(C_{j}\right)$ and at the province level $i\left(C_{j i}\right)$.

Step 2: Compute the "Per-client Expenditure Norm", calculated as the ratio between the aggregate level of provincial expenditure per function $j\left(S E N_{j}\right)$ and the number of users of function $j$ at the national level $\left(C_{j}\right)$, or

$$
\text { Per Client Exp Norm }=S E N_{j} / C_{j} \text {. }
$$

Step 3: Compute the "Expenditure Needs" $\left(E N_{j i}\right)$ of each province $i$ for every function $j$ as a product of the Per-client Expenditure Norm (calculated in Step 2) and the number of users of function $j$ in province $i\left(C_{j i}\right)$, or

$$
E N_{j i}=\left(S E N_{j} / C_{j}\right) C_{j i}
$$

The "Total Expenditure Needs" $\left(E N_{i}\right)$ for each province $i$ is the sum of expenditure needs for all functions in a particular province, or

$$
E N_{i}=\sum_{\mathrm{j}} E N_{j i}
$$


Step 4: Obtain the "Per-capita Expenditure Need" for each province $i$ and each function $j$ as the ratio of the Expenditure Needs obtained in Step 3 and the total population $P_{i}$ of province $i$.

\section{Data}

Data on provincial expenditure per function are obtained from the Intergovernmental Fiscal Review (IGFR) 2007, and from Provincial Budgets and Expenditure Reviews 2003/04-2009/10. Data on total population and population by age are obtained from the Statistics South Africa and on HIV infected from "Demographic Impact of HIV/AIDS in South Africa, National and Provincial Indicators for 2006", Centre of Actuarial Research. Note that the function "Transport" includes "Public Works" and "Roads and Transport", and "Other" includes "Other Services" other than those included in function "Transport".

\section{Assumptions on Potential Users}

- In case of education services (primary and secondary), users of these services at the provincial level are the population between 5 and 19 years old.

- In the case of health services, users of these services are children 5 or less year old and elderly 65 and more years old. An alternative exercise includes HIV infected population as potential users of health services. It is assumed (for simplicity) that all groups (children, elderly, and HIV infected) are equally weighted in calculating the expenditure norm and needs.

- In the case of case of social development, group users of these services are the population below the poverty line. Due to limited data availability, it is assumed that the poverty ratio is constant over the observed period, as provided in PES Data Requirements provided by South Africa authorities.

- Due to lack of data on local roads, provincial area is used to calculate the expenditure needs for transportation.

- In case of housing, agriculture, and other services, users are the total population.

\section{Results}

Table A.1 summarizes the main results from this method.

TABLE A.1. ESTIMATED PROVINCIAL EXPENDITURE NEEDS USING PERCLIENT FINANCIAL EXPENDITURE NORMS, AVERAGE FOR 2005 TO 2007 (IN 1000 RANDS)

\begin{tabular}{|l|c|c|c|}
\hline Province & $\begin{array}{c}\text { Actual } \\
\text { Expenditure }\end{array}$ & $\begin{array}{c}\text { Per Client } \\
\text { Expenditure Norms }\end{array}$ & $\begin{array}{c}\text { Per Client Expenditures } \\
\text { Norms (with HIV) }\end{array}$ \\
\hline Eastern Cape, EC & $27,198,344$ & $29,727,541$ & $28,699,538$ \\
\hline Free State, FS & $12,096,784$ & $12,284,898$ & $12,489,025$ \\
\hline Gauteng, GT & $34,055,565$ & $27,940,540$ & $29,618,071$ \\
\hline KwaZulu-Natal, KZN & $37,934,356$ & $37,722,225$ & $39,120,193$ \\
\hline
\end{tabular}




\begin{tabular}{|l|c|c|c|} 
Limpopo, LIM & $23,378,092$ & $23,470,707$ & $22,258,204$ \\
\hline Mpumalanga, MPU & $13,503,880$ & $14,131,646$ & $14,257,045$ \\
\hline Northern Cape, NC & $4,729,173$ & $9,936,055$ & $9,632,125$ \\
\hline North West, NW & $14,190,768$ & $13,533,043$ & $13,799,783$ \\
\hline Western Cape, WC & $18,777,778$ & $17,118,083$ & $15,990,754$ \\
\hline TOTAL, SA & $185,864,739$ & $185,864,739$ & $185,864,739$ \\
\hline
\end{tabular}

Source: Calculations by authors.

\section{APPENDIX B. COMPUTING FISCAL CAPACITY}

\section{Method: "Average (3 Years) Relative Per Capita Fiscal Capacity"}

Aggregate own fiscal capacity $(F C)$ of individual province $i\left(K_{i}\right)$ for the last three financial years, $2005 / 06$ to 2007/08 is listed in column 6, using the formula:

$$
\begin{gathered}
K_{i}=\left[\sum \text { Aggregate per capita revenue yield at provincial level }\right] / \\
{\left[\sum \text { Aggregate per capita revenue yield at the national level }\right] / \mathrm{A}}
\end{gathered}
$$

where

$$
\begin{aligned}
& K_{i}=[\text { Column } 3+\text { Column } 4] / \text { Column2 } / A \\
& A=[\text { Total } 3+\text { Total } 4] /(\text { Total } 2)=0.7084
\end{aligned}
$$

Similarly, for calculation of fiscal capacity inclusive of PES transfers, the logic is the same except that PES receipts are included.

\section{Data}

Data on the aggregate population of individual provinces for the average of 2005/06 to 2007/08 in South Africa, projected on the basis of Census 2001, are given in Table B.1, column 2. Aggregate own revenue, aggregate non-PES transfers from central government, and aggregate PES transfers of the last three years are reported in columns 3,4 , and 5, respectively. Individual years give similar results, and are not reported.

\section{Results}

The aggregate results for the last three years (Table B.1, column 6) show that Western Cape has the highest relative per capita own fiscal capacity, producing 49.3 percent more than at the national level; Mpumalanga lags behind the other provinces producing 33.5 percent less than at the national level. When PES transfers are also included (Table B.1, column 7), the situation changes significantly. See Figure B.1 for the overall degree of equalization under this method. 
TABLE B.1. AVERAGE (3 YEARS) RELATIVE PER CAPITA FISCAL CAPACITY FOR FY 2005/06 TO FY 2007/08

(IN 1000 RANDS)

\begin{tabular}{|c|c|c|c|c|c|c|}
\hline Province & Population & $\begin{array}{c}\text { Own } \\
\text { Revenue }\end{array}$ & $\begin{array}{l}\text { Non-PES } \\
\text { Transfers }\end{array}$ & PES & $\begin{array}{c}\text { Relative } \\
\text { Own Fiscal } \\
\text { Capacity } \\
\end{array}$ & $\begin{array}{c}\text { Fiscal } \\
\text { Capacity with } \\
\text { PES } \\
\end{array}$ \\
\hline 1 & 2 & 3 & 4 & 5 & $6=(3+4) / 2 / A$ & $7=(3+4+5) / 2 / B$ \\
\hline Eastern Cape, EC & $6,891,909$ & 739,271 & $3,008,511$ & $24,680,848$ & 0.768 & 1.051 \\
\hline Free State, FS & $2,958,323$ & 475,656 & $1,804,534$ & $9,686,441$ & 1.088 & 1.030 \\
\hline Gauteng, GT & $9,518,551$ & $2,101,835$ & $7,661,312$ & $24,146,245$ & 1.448 & 0.907 \\
\hline KwaZulu-Natal, KZN & $9,920,460$ & $1,240,289$ & $4,120,484$ & $32,540,581$ & 0.763 & 0.973 \\
\hline Limpopo, LIM & $5,368,229$ & 471,089 & $2,088,257$ & $20,472,812$ & 0.673 & 1.093 \\
\hline Mpumalanga, MPU & $3,508,251$ & 375,249 & $1,276,270$ & $11,798,707$ & 0.665 & 0.976 \\
\hline Northern Cape, NC & $1,094,577$ & 121,667 & 848,556 & $3,730,426$ & 1.251 & 1.094 \\
\hline North West, NW & $3,371,580$ & 515,145 & $1,695,351$ & $11,823,450$ & 0.925 & 1.060 \\
\hline Western Cape, WC & $4,741,160$ & $1,722,179$ & $3,293,855$ & $13,559,142$ & 1.493 & 0.998 \\
\hline South Africa, SA & $47,373,039$ & $7,762,380$ & $25,797,130$ & $152,438,651$ & 1.000 & 1.000 \\
\hline
\end{tabular}

Source: Calculations by authors.

Note: Population is aggregate projected census data based on census 2001 for years 2005/06 to 2007/08, and Own Revenue is an aggregate figure for financial years 2005/06 to $2007 / 08$

FIGURE B.1. PERCENTAGE INCREASE/DECREASE IN RELATIVE PER CAPITA FISCAL CAPACITY AFTER EQUALIZATION USING RELATIVE OWN FISCAL CAPACITY

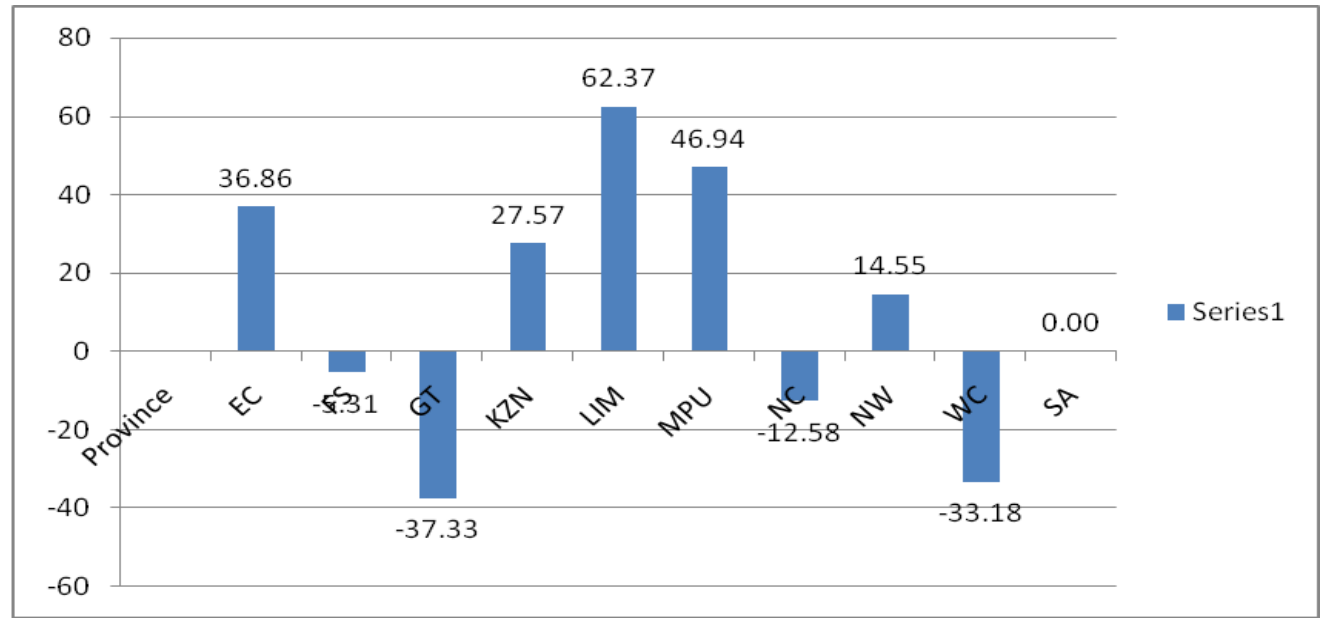

Source: Calculations by authors. 


\section{REFERENCES}

Alm, James and Jorge Martinez-Vazquez, "On the Use of Budget Norms as a Tool for Fiscal Management”, Public Finance and Management, 2002, Vol.2. No. (3), pp. 387-435.

Bahl, Roy and Johannes Linn, Urban Public Finance in Developing Countries, 2007, Oxford University Press, Oxford, UK.

Bahl, Roy, and Paul Smoke (Editors), Restructuring Local Government Finance in Developing Countries: Lessons from South Africa, 2003, Edward Elgar Publishing, Cheltenham, UK.

Bird, Richard M. and Francois Vaillancourt (Editors), Fiscal Decentralization in Developing Countries, 1998, Cambridge University Press, Cambridge, UK.

Blöchliger, Hansjörg and Claire Charbit, "Fiscal Equalization". OECD Economic Studies, 2008, Vol. 44, No. 1, pp. 265-286.

Boex, Jameson and Jorge Martinez-Vazquez, Local Government Financial Reform in Developing Countries: The Case of Tanzania, 2006, Palgrave-Macmillan Publishing, New York, NY.

Boex, Jameson and Jorge Martinez-Vazquez, "Designing Intergovernmental Equalization Transfers with Imperfect Data: Concepts, Practices, and Lessons", in Challenges in the Design of Fiscal Equalization and Intergovernmental Transfers, 2007, Jorge Martinez-Vazquez and Bob Searle, Editors, Springer Publishing, New York, NY, pp. 291-343.

Dollery, Brian, "An Initial Evaluation of Revenue-sharing Arrangements in the New South African Fiscal Federalism”. Publius: The Journal of Federalism , 1998, Vol. 28, No. 2, pp. 129-153.

Financial and Fiscal Commission, For an Equitable Sharing of National Revenue, 2000, Republic of South Africa, Pretoria, South Africa.

Litvack, Jennie, Junaid Ahmad, and Richard M. Bird, Rethinking Decentralization in Developing Countries, 2008, The World Bank, Washington, D.C.

Martinez-Vazquez, Jorge and Bob Searle (Editors), Fiscal Equalization: Challenges in the Design of Intergovernmental Transfers, 2007, Edward Elgar Publishing, Cheltenham, UK.

Oates, Wallace E., Fiscal Federalism, 1972, Harcourt Brace Jovanovich, Inc., Englewood Cliffs, NJ.

Oates, Wallace E., “An Essay on Fiscal Federalism”, The Journal of Economic Literature, 1999, Vol. 37, No. 4, pp. 1120-1149.

Oates, Wallace E., "Toward a Second-generation Theory of Fiscal Federalism", International Tax and Public Finance, 2005, Vol. 12, No. 4, pp. 349-373.

Shah, Anwar, The Reform of Intergovernmental Fiscal Relations in Developing and Emerging Market Economies, 1994, The World Bank, Washington, D.C.

Simeon, Richard and Christina Murray, "Multi-sphere Governance in South Africa: An Interim Assessment", Publius: The Journal of Federalism , 2001, Vol. 31, No. 4, pp. 65-92.

Wehner, Joachim, "Fiscal Federalism in South Africa", Publius: The Journal of Federalism, 2000, Vol. 30, No. 3, pp. 47-72. 
Weingast, Barry R., "Second Generation Fiscal Federalism: Political Aspects of Decentralization and Economic Development", World Development, 2014, Vol. 53, No. 1, pp. 14-25.

Yonatan, Fessha and Coel Kirkby, "A Critical Survey of Subnational Autonomy in Africa States", Publius: The Journal of Federalism, 2008, Vol. 38, No. 2, pp. 248-271.

\section{ENDNOTES}

Acknowledgement

* We are grateful to Kenneth Brown, Bongani Khumalo, Eddie Rabake, an anonymous referee, and the Editor, Abu Wahid, for helpful comments and support. We also thank Mushtaq Ahmad, Violeta Vulovic, and Nyda Mukhtar for able research assistance. Please address all correspondence to: James Alm, Department of Economics, Tulane University, 208 Tilton Hall, 6823 St. Charles Avenue, New Orleans, LA 70118 (phone +1 504862 8344; fax +1 504865 5869; email jalm@tulane.edu).

${ }^{1}$ For recent discussions and analyses of equalization schemes around the world, see MartinezVazquez and Searle (2007) and Blöchliger and Charbit (2008).

2 For a general discussion of the design of federal systems, see Bahl and Linn (1992), Shah (1994), Bird and Vaillancourt (1998), Oates (1972, 1999), Boex and Martinez-Vazquez (2006), and Litvack, Ahmad, and Bird (2008), all of which also contain discussion of transfer design. A more recent development in the theory of fiscal federalism emphasizes more explicitly the role of political and other institutions. See especially Oates (2005) and Weingast (2014).

${ }^{3}$ See Dollery (1998), Wehner (2000), Simeon and Murray (2001), and Bahl and Smoke (2003) for recent analyses of various federalism issues in South Africa, and Yonatan and Kirkby (2008) for a more general analysis in other parts of Africa.

${ }^{4}$ South Africa has traditionally used some form of historical costs, albeit in the form of historical expenditure patterns.

${ }^{5}$ Of course, there exist a variety of alternatives to allocate $X$ according to the computed fiscal disparities. For instance, those subnational governments with a higher $D_{i}$ might receive transfers in a higher proportion. A particular case under this scheme would be to set a maximum fiscal disparity, so that transfers would be provided only to those governments with the highest $D_{i}$ until all of them reach such a maximum.

${ }^{6}$ In order to make the objective of horizontal equalization compatible with the right incentives for provincial authorities, certain general principles must be considered while establishing the measurement methodology. First, both the expenditure needs and the fiscal capacity of each subnational government should be defined by means of impartial criteria that properly represent the objective of horizontal equalization. Second, subnational government officials should not have any type of influence on the indicators used to compute fiscal disparities. If they have such influence, then they may attempt to appear to have higher relative expenditure needs or to reduce their tax collection and fiscal effort, thus limiting the effectiveness and benefits associated with the equalization transfer system. For example, the use of historical information tends to be a bad instrument because the current policies are historical in the next period (s), and the authorities may decide to take advantage of the system without taking into account the costs at a national level.

${ }^{7}$ The costed norm approach has often been recommended by the Financial and Fiscal Commission of the Republic of South Africa. For example, see Financial and Fiscal Commission (2000). 
${ }^{8}$ There are other considerations, including procedural issues, that must be considered. Top-down financial norms need to be determined simultaneously with the budget. Ultimately the budget must reflect the government spending policy priorities, and the per-client norms must also reflect those government priorities. For example, if the government decides to make general basic education a more important policy priority, then this should be reflected in increases for the per student financial norm for basic education. All of these process issues can be controversial, so that the perclient norm methodology requires a well-ordered and transparent budget process.

9 The representative tax system measure is calculated by first estimating the tax bases in each local government and then by applying a set of common tax rates (representing an equal level of fiscal effort) to these bases. Those jurisdictions that have a lower fiscal capacity with respect to a certain threshold or standard are selected as the beneficiaries of the transfer program.

10 See Boex and Martinez-Vazquez (2007) for methods to design transfers when data are incomplete. 